\title{
CHRONIC KIDNEY DISEASE IN HEPATITIS B AND C PATIENTS: A SYSTEMATIC OVERVIEW
}

\author{
Sukanya Tripathy ${ }^{1,2}$, Amar Deep ${ }^{1,2}$, Suchit Swaroop ${ }^{2}$, Sant Pandey ${ }^{3}$, Ajay Kumar ${ }^{1}$, Sumit Rungta ${ }^{1}$ \\ 1. Department of Medical Gastroenterology, King George Medical University, Lucknow. \\ 2. Department of Zoology, University of Lucknow. \\ 3. Department of Nephrology, King George Medical University, Lucknow
}

\begin{abstract}
Developing countries like India face a unique challenge in managing disease like chronic kidney disease. Early detection and treatment is mandate to cope up with the renal failure and its comorbidities. In few of the cases development of hepatitis also occurs which further worsen the situation. Hepatitis being the blood borne virus affects the patient in most of the cases with renal failure. The advent of effective nucleotide analogs (NAs) has bid the chance to minimize the effects of hepatitis B virus (HBV) infection in HBV-positive patients with chronic kidney disease. Combination with immunosuppressive agents is most favorable in rapid renal function impairment. Other concern is the infection of hepatitis $\mathrm{C}$ virus (HCV). It represents a major medical and epidemiologic challenge in patients with renal replacement therapy with dialysis or transplantation. In this scenariothe presence of $\mathrm{HCV}$ correlates with higher rates of mortality than in HCVnegative subjects on dialysis or undergoing kidney transplant poses a major concern. Thus, the present review deals with the basics of CKD and its correlate with the hepatitis. Further we will also look into the effect of hemodialysis on hepatitis patients and their major concerns.
\end{abstract}

Keywords - Renal disease, Chronic Kidney Disease (CKD), Hepatitis B Virus (HBV), Hepatitis CVirus (HCV), Hemodialysis

\section{INTRODUCTION}

The renal failure with its high prevalence, morbidity and mortality, is an important public health issue to deal with. In most of the developing countries like India, there are large numbers of patients below the poverty line who suffer with the low monetary allocations for health care and thus, it adds to the health problem along with the metabolic alterations.

Diseases like renal and hepatic diseases are also ignored in front of communicable infectionsare usually as they may cause epidemic conditions in the society [Appel et al. (2005)]. Kidney failure is also known as an end-stage renal disease (ESRD) which is the, last stage of chronic kidney disease. The condition notifies when the kidney have stopped working well enough for patient to survive without dialysis or a kidney transplant. The damage is not a one-day process, it occurs over a long period of time. In earlier days it remain asymptomatic but in later stages the condition may get worsen and kidneys are less able to do the job and this is clinically defined as chronic kidney disease (CKD).

To cope up with renal complications hemodialysis is a frequently used measure. The patients undergoing hemodialysis are at much higher risk of developing blood borne infections such as $\mathrm{HBV}$ and $\mathrm{HCV}$ due to prolonged vascular access and a longer period of exposure to contaminated equipment. The symptoms of hepatitis are more common in dialysis patients as compared to non-dialysis patients [Tang et al. (2005), Furusyo et al. (2000), Fabrizi et al. (2010)]. Symptoms were found to be more constant with the age and number of transfusion products [Furusyo et al. (2000)]. Similar to HCV, it was studied for hepatitis B virus (HBV) which also has a complex relationship to kidney diseases. It was studied with chronic HBV infection that it plays an etiologic factor in secondary glomerular diseases. The HBV patients pose a critical impact on the clinical management of kidney transplant recipients and patients with renal diseases who are treated with immunosuppressive drugs. In this review chronic kidney disease is discussed followed by hepatitis and its effect on hemodialysis patients.

\section{CHRONIC KIDNEY DISEASE (CKD)}

Chronic kidney disease refers to a state where the kidneys are damaged and have lost their potential of filtration, thus unable to filter the blood in appropriate manner. The chief risk factors for developing kidney disease include diabetes, high blood pressure, heart disease, and a family history of renal failure [Rajapurkar et al. (2012)]. Demographic data presented by United Nations Children's Emergency Fund show that amongst total population $28 \%$ of children are $2.5 \mathrm{~kg}$ at birth leading to hypovitaminosis $\mathrm{A}$ and other nutritional issues causing reduction in kidney volume at birth and a lower eGFR [Varughese et al. (2007)]. Issues like poverty, poor sanitation, pollutants, water contamination, overcrowding, and nephrotoxins may lead to glomerular and interstitial kidney diseases. Apart from these genetic conditions like 


\section{International Journal of Engineering Applied Sciences and Technology, 2020 \\ Vol. 4, Issue 10, ISSN No. 2455-2143, Pages 352-358 \\ Published Online February 2020 in IJEAST (http://www.ijeast.com)}

hypertension and diabetes mellitus further worsen the condition. Due to poor availability of diagnostic tools and challenges in access to care almost $50 \%$ of patients with advanced CKD are reported when the eGFR is, $15 \mathrm{ml} / \mathrm{min}$ per $1.73 \mathrm{~m}^{2}$. This high percentage for grounds the need for fullbodied screening programs for those at risk for CKD. The reported prevalence of $\mathrm{CKD}$ in different regions ranges from, $1 \%$ to $13 \%$, and recently, data from the International Society of Nephrology's Kidney Disease Data Center Study reported a prevalence of $17 \%$ [Ene-Iordache et al. (2012)].

\section{STAGES OF CKD AND GFR RANGE}

Glomerular filtration rate (GFR) is the most accurate assess of kidney function. It is calculated by using the person's age and their serum creatinine level. Creatinine is obtained from blood report as it is a waste product that comes from muscle activity.

According to the GFR rate the practitioners divide CKD in five stages. The stages and their calculation are summarized in the table:

Table 1: Stages of Chronic Kidney Disease and their Glomerular Filtration Rate (https://www.disabledworld.com/health/cancer/kidney/gfr-ckd.php).

\begin{tabular}{|c|c|c|c|c|}
\hline Stage 1 & $\begin{array}{ll}\text { Normal or } \\
\text { high }\end{array}$ & \multicolumn{3}{|c|}{ GFR $>90 \mathrm{~mL} / \mathrm{min}$} \\
\hline Stage 2 & Mild CKD & $\begin{array}{r}\text { GFR } \\
\mathrm{mL} / \mathrm{min}\end{array}$ & 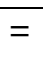 & 60-89 \\
\hline Stage 3A & $\begin{array}{l}\text { Moderate } \\
\text { CKD }\end{array}$ & $\begin{array}{r}\text { GFR } \\
\mathrm{mL} / \mathrm{min}\end{array}$ & - & $45-59$ \\
\hline Stage 3B & $\begin{array}{l}\text { Moderate } \\
\text { CKD }\end{array}$ & $\begin{array}{r}\text { GFR } \\
\mathrm{mL} / \mathrm{min}\end{array}$ & & $30-44$ \\
\hline Stage 4 & Severe CKD & $\begin{array}{r}\text { GFR } \\
\mathrm{mL} / \mathrm{min}\end{array}$ & $=$ & 15-29 \\
\hline Stage 5 & $\begin{array}{l}\text { End } \\
\text { CKD }\end{array}$ & GFR & $5 \mathrm{~m}$ & $\min$ \\
\hline
\end{tabular}

When kidneys are working well, they remove creatinine from the blood. As kidney function slows, blood levels of creatinine rise.The disease usually get worse slowly, and the patient is asymptomatic until kidneys are badly damaged. In the subsequent stages of CKD the patient also may notice symptoms that are caused by waste and extra fluid building up in the body. The usual symptoms developed may be depicted as follows:

Figure 1: Symptoms of Chronic Kidney Disease

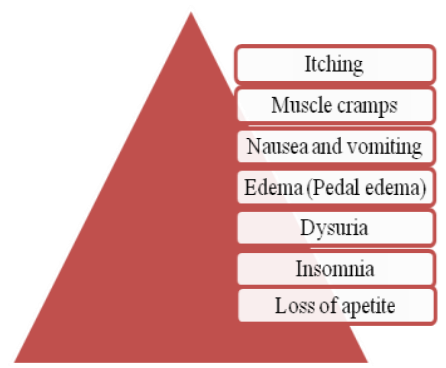

\section{HEPATITIS B VIRUS (HBV)}

The structure of hepatitis virus consists of nucleocapsid involved in packaging of viral genome which is approximately $28 \mathrm{~nm}$ in size and comprises core antigen. The membrane encapsulating the Dane particle is derived from secretory pathway via Golgi apparatus and endoplasmic reticulum. Outer membrane envelope forms $\mathrm{HBsAg}$ which posses the antigenic property by forming complex antigenic determinant. It contains three viral surface proteins named according to their size of small, middle and large as $\mathrm{HBsAg}, \mathrm{HBmAg}$ and $\mathrm{HBlAg}$ respectively. While studying the molecular basis of its structure it was found that they are coded by the same ORFs as of start codon and get overlaps with polymerase ORF [Seeger et al. (2000)]. Template for replication is served by the pregenomic RNA. Viral polymerase is the only enzyme encoded and is also located in the nucleocapsid [Summers et al. (1982)]. The structure of hepatitis virus is depicted in the figure underneath: (Sherris Medical Microbiology, 7eChapter 13: Hepatitis Viruses).

Figure 2: Structure of Hepatitis B Virus

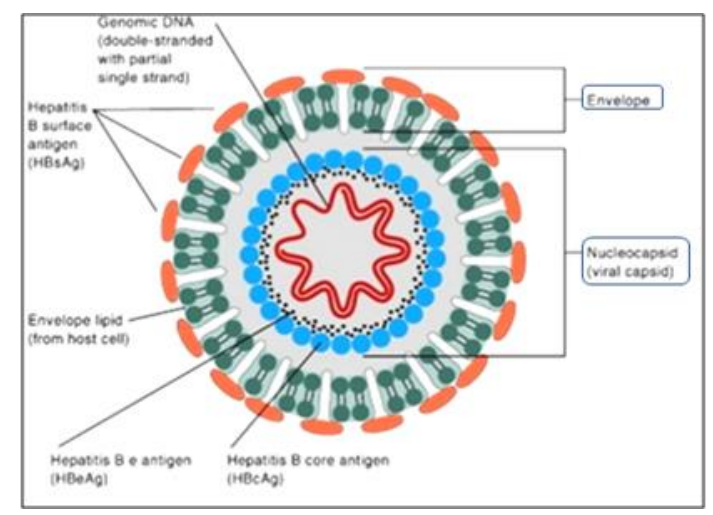

Another translation product of core gene include hepatitis B envelope antigen ( $\mathrm{HBeAg}$ ). For the translation of $\mathrm{HBeAg}$, an upstream pre-core region with ATG codon is required [Tong et al. (2012)]. The HBeAg is an important component in the diagnosis of $\mathrm{HBV}$ infection which acts as an active marker for viral replication [Chen et al. (2004)]. As visualized in the image virus contains two DNA strands:

- $\quad$ long [L (negative) strand] fixed length of $3.2 \mathrm{~Kb}$

- $\quad$ short [S (positive) strand] the length is variable at its 3 ' end. The S strand usually spans $50 \%$ to $100 \%$ of the length of the L strand.

\section{$>$ Epidemiology of HBV}

Hepatitis B as is previously discussed a blood-borne virus spread through percutaneous or mucosal exposure to infected blood or body fluids [Baijal et al. (2014)]. According to recent studies there are more than 350 million people worldwide with chronic hepatitis B (CHB) infection [Saravanan et al. (2008)]. India lies in the intermediate endemicity zone with the 


\section{International Journal of Engineering Applied Sciences and Technology, 2020 \\ Vol. 4, Issue 10, ISSN No. 2455-2143, Pages 352-358 \\ Published Online February 2020 in IJEAST (http://www.ijeast.com)}

prevalence of $2-7 \%$, with an average of $4 \%$ and a disease burden of about 50 million. Most vulnerable population is found in the tribal areas where due to low awareness rate the high burden is maintained through intercaste marriages, customs, illiteracy and miserable health care resources. The mode of transmission of chronic hepatitis B (CHB) in India is horizontal transmission in early childhood (mostly from family contacts) and to lesser extent by perinatal transmission. The risk factors may include contact of cut skin or mucous membranes with tears, saliva or blood containing HBVinfected secretions. The age of acquisition of $\mathrm{HBV}$ is an important determinant of outcome; the earlier the age, the higher the risk of chronicity.

The disease is known to occur in three stages during its natural history -

(a) Immunotolerant phase: in this the $\mathrm{HBe}$ is +ve and high DNA load with normal enzymes

(b) Immune active phase: with heave in enzymes, hepatitis B e antigen ( $\mathrm{HBeAg}$ ) negativity and clearance of DNA, and

(c) Inactive carrier phase with development of $\mathrm{HBe}$ antibody (antiHBe), normal enzyme levels and negativity for $\mathrm{HBV}$ DNA.

The possible causes of lasting viral infection are due to high viral load, rapid replication, viral inhibition of antigen presentation, viral mutations that antagonize antigen recognition, immunosuppressive effects of virus etc. [Sprengers et al. (2005)].

\section{$>\mathrm{HBV}$ in renal disease}

During the study of renal failure it was sometimes visualized the case of chronic HBV infection. Manifestation of the disease is by immunity mediated glomerulopathy in which the virus particles are identified in different areas of glomeruli. For treatment of $\mathrm{HBV}$-associated renal disease KDIGO (Kidney Disease: Improving Global Outcomes) indicated that patients should be treated according to standard clinical practice guidelines for $\mathrm{HBV}$ infection. The latest metaanalysis [Pipili et al. (2013)] on handling of HBV-associated glomerulonephritis reasoned that the combined therapy of antiviral and immunosuppressant is an effective regimen without hindering the HBV replication or damaging liver and renal function [Srivastava et al. (2013)]. Next step is to determine the therapy which should always be made on an individual basis via a multidisciplinary approach decided by the patient's age, baseline viral levels, type of renal disease, risk of resistance, and drug renal protective profile. For all the patients with chronic HBV infection long-term NA therapy is generally recommended irrespective of the presence of renal disease. In some of the cases NA therapy may be discontinued like:

patients with $\mathrm{HBeAg}$ positive chronic $\mathrm{HBV}$ infection who achieve stable HBeAg seroconversion and $\mathrm{HBV}$ DNA undetectability for at least 12 months
In patients with $\mathrm{HBeAg}$-negative chronic $\mathrm{HBV}$ infection who achieve HBsAg loss.

The maximal tenure of antiviral therapy for $\mathrm{HBV}$-associated nephropathy is not specific it varies person to person and in most of the cases long-term antiviral treatment is recommended. Some of the commonly used drugs are tabulated as under: [Zheng et al. (2012)].

Table 2: Drugs for HBV Treatment

\begin{tabular}{|c|l|}
\hline Drugs & \multicolumn{1}{|c|}{ Effect } \\
\hline Telbivudine & $\begin{array}{l}\text { favorable effect on renal function } \\
\text { [Gane et al. (2014)] }\end{array}$ \\
\hline Entecavir & $\begin{array}{l}\text { resistance profile in NA-naive } \\
\text { patients1 and has been reported to be } \\
\text { safe and effective in a few patients with } \\
\text { HBV-related glomerular disease } \\
\text { [Numata et al. (2011)] }\end{array}$ \\
\hline $\begin{array}{c}\text { Tenofovir and } \\
\text { Emtricitabine }\end{array}$ & $\begin{array}{l}\text { HIV-HBV coinfected patient with } \\
\text { membranous nephropathy [Guillevin et } \\
\text { al. (2005)] }\end{array}$ \\
\hline Rituximab & $\begin{array}{l}\text { suppression of vasculitis-and } \\
\text { for } \\
\text { plasma exchange (European Association } \\
\text { For The Study Of The Liver) for } \\
\text { removal of circulating immune } \\
\text { complexes- may be gainful for } \\
\text { ameliorating kidney function and disease } \\
\text { manifestations }\end{array}$ \\
\hline
\end{tabular}

\section{HePATITIS C VIRUS (HCV)}

Genome size of $\mathrm{HCV}$ is $9.5 \mathrm{~Kb}$ with conserved untranslated regions on both 5' and 3' termini of the genome. The UTRs are further flanked by a large translational ORF which encodespolyprotein of 3000 amino acids. Its structure contains an uncapped 5' noncoding region, of approximately 340 nucleotides, comprises of internal ribosomal entry site (IRES) which is essential for cap independent translation of viral RNA. The 3' region of the genome contains noncoding regions. The polyprotein encoded by the genome is later co and post transcriptionally processed by various cellular and viral enzymes [Moradpour et al., Dalekos et al. (1998)] The detailed molecular structure is depicted in the following figure: [Kohji et al. (2012)]. 


\section{International Journal of Engineering Applied Sciences and Technology, 2020 \\ Vol. 4, Issue 10, ISSN No. 2455-2143, Pages 352-358 \\ Published Online February 2020 in IJEAST (http://www.ijeast.com)}

Figure 3: Molecular structure of Hepatitis C Virus

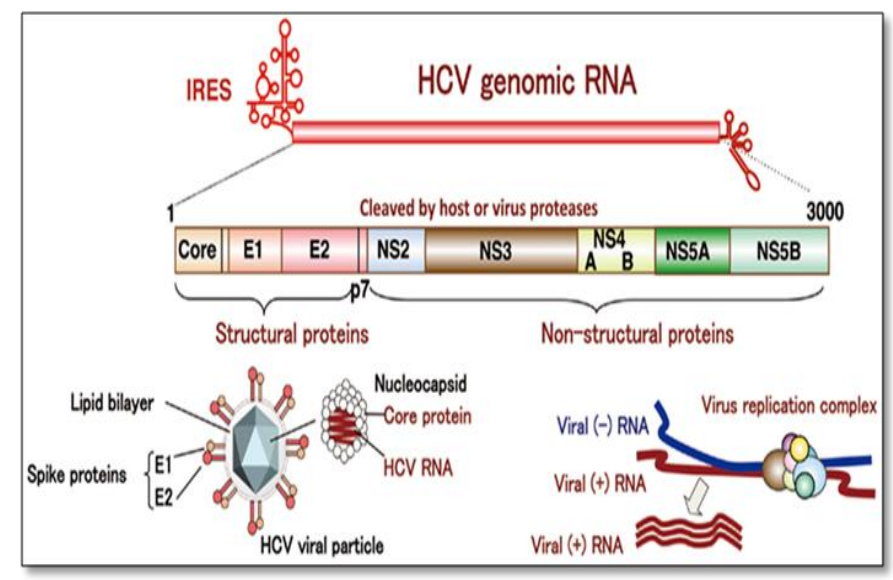

\section{$>$ Epidemiology of $\mathrm{HCV}$}

Though the variations are found in studies across the geographical regions, the prevalence of $\mathrm{HCV}$ infection in India is about $1-1.9 \%$ [Sievert et al. (2011)]. In a populationbased study performed by Chowdhury et al. from West Bengal, 3579 individuals were preselected and the seroprevalence of $\mathrm{HCV}$ antibody positivity was noted in $0.87 \%$. The prevalence showed an enhancing drift from $0.31 \%$ in children aged below 10 years to $1.85 \%$ in adults aged 60 years or more [Chowdhury et al. (2003)]. Similar study conducted in New Delhi, 28,956 healthy blood donors were tested and the prevalence of anti-HCV was noted in $0.66 \%$ [Pahuja et al. (2007)]. The prevalence is more in $\mathrm{HCV}$ infection in high-risk group of patients like those receiving blood transfusions (patients with thalassemia major), subjects with IVDU, HCWs, subjects on hemodialysis (HD) is expected to be higher than in general population. In a study by Chakravarti et al. (2013) from New Delhi, 51 patients with anti-HCV positivity were enrolled and iatrogenic procedures were found to be responsible for transmission of $\mathrm{HCV}$ in $83.3 \%$ of patients with blood transfusion alone responsible in 67\%. Jasuja et al. (2009) in their study on 119 patients receiving $\mathrm{HD}$ noted $\mathrm{HCV}$ infection in $27.7 \%$. Longer duration of $\mathrm{HD}$ and getting $\mathrm{HD}$ at more than one centre are deemed important in acquiring $\mathrm{HCV}$ infection.

Genotype 3 is among the most frequent genotype reported in India accounts for $54-80 \%$ of cases. [Verma et al. (2008)] Studies from northern, western and eastern parts of the country have uniformly shown predominance of genotype 3 ; however, in southern India, both genotypes 1 and $3 \mathrm{HCV}$ are found to be prevalent. [Narahari et al. (2009), Chandra et al. (2007)].

\section{$>\mathrm{HCV}$ in renal disease}

It was found through biochemical evaluation that the level of ALT (alanine aminotransferase) in HCV infection considerably increases in serum, thus it is considered a nonspecific marker of liver damage. Although ALT concentration is a molecular marker for hepatitis it is rather weak for patients with renal failure due to vitamin B6 deficiency, presence of uremic toxins, or UV-absorbing components in the blood that could interpolate the transaminase sensing [Schneeberger et al. (1998)]. The presence of anti HCV antibodies by ELISA allows rare falsenegative results in dialysis patients [Poynard et al. (2003), Pawa et al. (2007)] but is not efficient in characterizing acute and chronic infection. Quantitative determination of viral load is also an effective prognostic tool for the infection because patients with high initial HCV RNA levels benefit more from 48-wk treatment [Özgiir et al. (1996)]. For diagnosis and treatment of the infection following options are being looked upon:

- $\quad$ IFN treatment [McHutchison et al. (1998)]

- Liver biopsy provides key information on the extent of $\mathrm{HCV}$ associated hepatic disease, but requires caution in CKD because of the potential low risk of bleeding complications, especially in patients with chronic kidney diseases [Pawa et al. (2007)]

- Transjugular biopsy

- Noninvasive method like fibroscan showed a better diagnostic performance in hemodialysis and renal transplant patients with $\mathrm{HCV}$ infection [Varaut et al. (2005)].

\section{HEMODIALYSIS AND VIRAL HEPATITIS}

The patients with higher levels of creatinine are directed for hemodialysis. Due to blood borne viral particles of HBV the prevention is necessary. The instauration of HBV\& $\mathrm{HCV}$ immunization has importantly depressed the incidence in several indigenous regions [Fabrizi et al. (2015)]. Although immunized some of the patients show the presence of virus. For management of these patients undergoing hemodialysis, physicians keeps continual checkup of blood and viral markers. Moderate or no elevations of serum aminotransferases are due to altered inflammatory response, and hence the lower serum HBV-DNA and HCV-RNA levels are the removal of blood by hemodialysis [Tseng et al. (2008)]. All these parameters may affect the clinical and laboratory presentation and course of chronic viral infection and the patient's response to antiviral therapy. The optimal therapy for chronic HBV infection on hemodialysis may involve observation, IFN-a, or NAs.

The eradication rate of $\mathrm{HCV}$ infection by antiviral therapy is high in hemodialysis patients rather than in those with normal renal function [Meyers et al. (2003), Zeuzem et al. (2000)]. The reason behind it is possibly the high antiviral drug plasma levels developed due to decreased renal clearance. It is noticed in the patients that the penetration of PEG-IFN is reduced by $45 \%$ in patients with ESRD [Thévenot et al. (2004)], due to the permeability and pore size of dialyzers. This may further lead to co-morbidities in dialysis patients [Barril et al. (2004)]. It was analyzed that if initially the viral load is low then the therapy of SVR works in a much better way. Combination of ribavirin with PEG-IFN is believed to be the best criterion of therapy in $\mathrm{HCV}$-positive patients with normal renal function 


\section{International Journal of Engineering Applied Sciences and Technology, 2020 \\ Vol. 4, Issue 10, ISSN No. 2455-2143, Pages 352-358 \\ Published Online February 2020 in IJEAST (http://www.ijeast.com)}

up to 50 to $60 \%$ [Kes et al. (2007)]. Although the physicians hesitate to use the combination in person with dialysis for the adverse effects of the drugs like hemolytic anemia, that can be exacerbated in the presence of ESRD [Fehr et al. (2004)].

Apart from all the therapies and drugs studied for the treatment, role of diet is also found to be very necessary. In one of the study performed by Amardeep et al., it is found that malnutrition is a frequent and integral component of acute as well as some of the chronic diseases including hepatitis and CKD. Therefore, every patient should have an assessment of their nutritional status. Patient with advanced liver or kidney infection commonly have malnutrition but its assessment is confounded by many of the usual indicators of nutritional status. Thus, we may see that the patients undergoing dialysis are more susceptible to the infection somewhere due to comorbidities the adverse effects of drugs well as lower nutritional status and lack of awareness of the subject.

\section{CONCLUSION}

Kidney and liver play an essential role in maintaining the metabolic functions in body. The kidney being important for ultrafiltration if is chronically damaged may also inhibit the function of liver in some or the other way. The CKD patients possessing higher value of creatnine underwent dialysis. These patients further due to blood borne infection carry higher chances of hepatitis infection. Thus the combinatorial drugs, healthy lifestyle and restricted diet are essential to make their life easier.

\section{Financial Support}

Financial assistance is provided by UP-CST.

Conflict of Interest

The authors have no conflicts of interest to declare.

\section{REFERENCE}

1. Appel N., Pietschmann T., and Bartenschlager R. (2005). Mutational Analysis of Hepatitis C Virus Nonstructural Protein 5A: Potential Role of Differential Phosphorylation in RNA Replication and Identification of a Genetically Flexible Domain. J Virol, (pp. 79:3187-3194).

2. Tang S., and Lai KN. (2005). Chronic viral hepatitis in hemodialysis patients. Hemodial Int, (pp. 9:169179).

3. Furusyo N., Hayashi J., Kanamoto-Tanaka Y., Ariyama I., and Etoh Y.(2000). Liver Damage in Hemodialysis Patients with Hepatitis C Virus Viremia: A Prospective 10-Year Study. Dig Dis Sci, (pp. 45:2221-2228).

4. Fabrizi F, Messa P, and Dixit V. (2010). Therapy with nucleos(t)ide analogues: current role in dialysis patients. Int J Artif Organs (pp. 33:329-38).

5. Rajapurkar MM, John GT, Kirpalani AL,Abraham G, Agarwal SK, and Almeida AF. (2012). What do we know about chronic kidney disease in India: first report of the Indian CKD registry. BMC Nephrol (pp. 13:10).
6. Varughese S, John GT, Alexander S, Deborah MN, Nithya N, and Ahamed I. (2007). Pre-tertiary hospital care of patients with chronic kidney disease in India. Indian J Med Res, (pp. 126).

7. Ene-Iordache B, Perico N, Bikbov B, Carminati S, Remuzzi A, and Perna A. (2016). Chronic kidney disease and cardiovascular risk in six regions of the world (ISN-KDDC): a cross-sectional study. Lancet Glob Heal, (pp. 4:e307-e319).

8. https://www.disabledworld.com/health/cancer/kidney/gfr-ckd.php.

9. Seeger C, and Mason WS. (2000). Hepatitis B virus biology. Microbiol Mol Biol Rev, (pp. 64:51-68).

10. Summers J, and Mason WS. (1982). Replication of the genome of a hepatitis B--like virus by reverse transcription of an RNA intermediate. Cell, (pp. 29:403-15).

11. Sherris Medical Microbiology, 7eChapter 13: Hepatitis Viruses.

12. Tong S, Kim K-H, Chante C, Wands J, and Li J. (2005). Hepatitis B Virus e Antigen Variants. Int J Med Sci, (pp. 2:2-7).

13. Chen MT, Billaud J-N, Sallberg M, Guidotti LG, Chisari FV, and Jones J. (2004). A function of the hepatitis B virus precore protein is to regulate the immune response to the core antigen. Proc Natl Acad Sci, (pp. 101:14913-14918).

14. Baijal R, Amarapurkar D, Praveen Kumar HR, Kulkarni S, Shah N, and Doshi S, (2014). A multicenter prospective study of infections related morbidity and mortality in cirrhosis of liver. Indian $\mathbf{J}$ Gastroenterol, (pp. 33:336-342).

15. Saravanan S, Velu V, Kumarasamy N, Shankar EM, Nandakumar S, and Murugavel KG. (2008). The prevalence of hepatitis $\mathrm{B}$ virus and hepatitis $\mathrm{C}$ virus infection among patients with chronic liver disease in South India. Int J Infect Dis, (pp. 12:513-518).

16. Sprengers D, and Janssen HL. (2005). Immunomodulatory therapy for chronic hepatitis B virus infection. Fundam. Clin. Pharmacol (pp.19, 1726).

17. Pipili CL, Papatheodoridis GV, and Cholongitas EC. (2013). Treatment of hepatitis B in patients with chronic kidney disease. Kidney International, (pp. 84, 880-885)

18. Srivastava M,Rungta S, Dixit V, Shukla S, Singh BT , Jain A. (2013). Predictors of survival in Hepatitis B virus related decompensated cirrhosis on tenofovir therapy: An Indian perspective. Antiviral research, (pp. 100).

19. Zheng X-Y, Wei R-B, Tang L, Li P, and Zheng XD,. (2012). Meta-analysis of combined therapy for adult hepatitis B virus-associated glomerulonephritis. World J Gastroenterol, (pp. 18:821).

20. Gane EJ, Deray G, Liaw Y-F, Lim SG, Lai CL, and Rasenack J, (2014). Telbivudine Improves Renal Function in Patients With Chronic Hepatitis B. Gastroenterology, (pp. 146:138-146).

21. Numata A, Akimoto T, Toshima M, IwazuY, Otani $\mathrm{N}$, and Miki T, (2011). Membranous nephropathy in 


\section{International Journal of Engineering Applied Sciences and Technology, 2020 \\ Vol. 4, Issue 10, ISSN No. 2455-2143, Pages 352-358 \\ Published Online February 2020 in IJEAST (http://www.ijeast.com)}

an HIV-positive patient complicated with hepatitis B virus infection. Clin Exp Nephrol, (pp. 15:769-773).

22. Guillevin L, Mahr A, Callard P, Godmer P, Pagnoux C, Leray E,. (2005). Hepatitis B virus-associated polyarteritis nodosa: clinical characteristics, outcome, and impact of treatment in 115 patients. Medicine (Baltimore), (pp. 84:313-22).

23. Moradpour D, and Blum HE. A primer on the molecular virology of hepatitis C. Liver Int, (pp. 24:519-525).

24. Dalekos G, Boumba DS, Katopodis K, Zervou E, Sferopoulos G, Elisaf M,. (1998). Absence of HCV viraemia in anti-HCV-negative haemodialysis patients. Nephrol Dial Transplant, (pp. 13:18041806).

25. Kohji M, and Yashiharu M. (2012). Exploitation of Lipid Components by Viral and Host Proteins for Hepatitis C Virus Infection. Front Microbio.

26. Sievert W, Altraif I, Razavi HA, Abdo A, Ahmed EA, AlOmair A. (2011). A systematic review of hepatitis $\mathrm{C}$ virus epidemiology in Asia, Australia and Egypt [Internet]. Liver Int, (pp. 31:61-80).

27. Chowdhury A, Santra A, Chaudhuri S, Dhali GK, Chaudhuri S, and Maity SG.(2003). Hepatitis C virus infection in the general population: A communitybased study in West Bengal, India. Hepatology, (pp. 37:802-809).

28. Pahuja S, Sharma M, Baitha B, and Jian M. (2007). Prevalence and trends of markers of hepatitis $C$ virus, hepatitis $\mathrm{B}$ virus and human immunodeficiency virus in Delhi blood donors: a hospital based study. Jpn J Infect Dis , (pp.60:389-91).

29. Chakravarti A, Ashraf A, and Malik S. (2013). A study of changing trends of prevalence and genotypic distribution of hepatitis $\mathrm{C}$ virus among high risk groups in North India. Indian J Med Microbiol, (pp. 31:354).

30. Jasuja S, Gupta A, Choudhry R, Kher V, Aggarwal DK, and Mishra A. (2009). Prevalence and associations of hepatitis $\mathrm{C}$ viremia in hemodialysis patients at a tertiary care hospital. Indian $\mathrm{J}$ Nephrol, (pp. 19:62).

31. Verma V, Chakravarti A, and Kar P. (2008). Genotypic characterization of hepatitis $\mathrm{C}$ virus and its significance in patients with chronic liver disease from Northern India. Diagn Microbiol Infect Dis, (pp. 61:408-414).

32. Narahari S, Juwle A, Basak S, and Saranath D. (2009). Prevalence and geographic distribution of Hepatitis C Virus genotypes in Indian patient cohort. Infect Genet Evol (pp. 9:643-645).

33. Chandra M, Thippavuzzula R, Ramachandra Rao VV, Habib AM, Habibullah CM, Narasu L. (2007). Genotyping of Hepatitis C virus (HCV) in infected patients from South India. Infect Genet Evol, (pp. 7:724-30).

34. Schneeberger PM, Keur I, van der Vliet W, van Hoek K, Boswijk H, and van Loon AM.(1998). Hepatitis C virus infections in dialysis centers in The Netherlands: a national survey by serological and molecular methods. J Clin Microbiol, (pp. 36:1711$5)$.

35. Poynard T, Yuen M-F, Ratziu V, and Lai CL. (2003). Viral hepatitis C. Lancet (London, England), (pp. 362:2095-100).

36. Pawa S, Ehrinpreis M, Mutchnick M, Janisse J, Dhar R, and Siddiqui FA. (2007). Percutaneous Liver Biopsy Is Safe in Chronic Hepatitis C Patients With End-Stage Renal Disease. Clin Gastroenterol Hepatol, (pp. 5:1316-1320).

37. Özgiir O, Boyacioglu S, Co M, Kart H, and Hasan TS. (1996). Percutaneous Liver Biopsy Complications in Patients with Chronic Renal Failure. Nephron (pp. 74, 442-443).

38. McHutchison JG, Gordon SC, Schiff ER, Shiffman ML, Lee WM, and Rustgi VK,. (1998). Interferon Alfa-2b Alone or in Combination with Ribavirin as Initial Treatment for Chronic Hepatitis C. N Engl J Med, (pp. 339:1485-1492).

39. Varaut A, Fontaine H, Serpaggi J, Verkarre V, Vallet-Pichard A, and Nalpas B,. (2005). Diagnostic accuracy of the fibrotest in hemodialysis and renal transplant patients with chronic hepatitis $\mathrm{C}$ virus. Transplantation, (pp. 80:1550-5).

40. Fabrizi F, Verdesca S, Messa P, and Martin P. (2015). Hepatitis C Virus Infection Increases the Risk of Developing Chronic Kidney Disease: A Systematic Review and Meta-Analysis. Dig Dis Sci, (pp. 60:3801-3813).

41. Tseng GY, Lin HJ, Fang CT, ChengYT, Huang CH, Tseng GC. (2008). Hemodialysis Reduces the Viral Load in Uremic Patients with Chronic Hepatitis B Infection. Ren Fail (pp. 30:1000-1005).

42. Meyers CM, Seeff LB, Stehman-Breen CO, and Hoofnagle JH. (2003). Hepatitis C and renal disease: an update. Am J Kidney Dis, (pp. 42:631-57).

43. Zeuzem S, Teuber G, Naumann U, Berg T, Raedle J, Hartmann S,.(2000). Randomized, Double-Blind, Placebo-Controlled Trial of Interferon Alfa2a With and Without Amantadine as Initial Treatment for Chronic Hepatitis C. Hepatology, (pp. 32:835-841).

44. Thévenot T, Regimbeau C, Ratziu V, Leroy V, Opolon P, and Poynard T. Meta-analysis of interferon randomized trials in the treatment of viral hepatitis $\mathrm{C}$ in naive patients. J Viral Hepat, (pp. 8:48-62).

45. Barril G, Quiroga JA, Sanz P, Rodriguez-Salvanes F, Selgas R, and Carreno V.(2004). Pegylated interferon-alpha2a kinetics during experimental haemodialysis: impact of permeability and pore size of dialysers. Aliment PharmacolTher, (pp.20:37-44).

46. Kes P, and Basic-Jukic N. (2007). Hepatitis C in Dialysed Patients - What Is the Current Optimal Treatment?. Kidney Blood Press Res, (pp. 30:156161).

47. Fehr T, and Ambuhl PM. (2004). Chronic hepatitis virus infections in patients on renal replacement therapy [Internet]. Nephrol Dial Transplant, (pp. 19:1049-1053). 
International Journal of Engineering Applied Sciences and Technology, 2020 Vol. 4, Issue 10, ISSN No. 2455-2143, Pages 352-358

Published Online February 2020 in IJEAST (http://www.ijeast.com)

48. Deep A. (2019). Malnutrition in Liver Cirrhosis Review. Journal of Clinical and Diagnostic Research, (pp. 10.7860/JCDR/2019/38412.12822). 